\title{
Special interest groups 1959 - 1980: Uneasy détente or collegial cold war?
}

\author{
Kathryn La Barre \\ Associate Professor \\ Graduate School of Library and Information Science \\ University of Illinois \\ klabarre@illinois.edu
}

ABSTRACT: An exploration of the events leading to the leading to the formation of the ASIS\&T Special Interest Group/ Classification Research (SIG/CR) - one of the first of the American Documentation Institute's SIGs, with context about other SIGs that formed during this same period.

Keywords

Special interest groups, ADI, ASIS, Classification Research

\section{INTRODUCTION}

This briefing aims to track the early beginnings of Special Interest Groups (SIGs) as part of the American Documentation Institute (ADI) as it evolved into the American Society for Information Science (ASIS). Today fifteen SIGs, and six Virtual SIGs consider the American Society of Information Science \& Technology (ASIS\&T) home, and ASIS\&T considers the SIGs "small professional organizations within the broader national society" (ASIS\&T website) Evidence collected in support of this proposal indicates that the process that resulted in the formation of contemporary SIGs was sometimes tense and impolitic. Many early SIGs failed to stand the test of time, or transformed into different SIGs.

This preliminary narrative is drawn from the internal publications of the American Documentation Institute, such as the News Notes, and position papers, and from the journal American Documentation. Archival sources from the following institutions provide the bulk of evidence: Case Western Reserve University Archives [CWRUA: Jesse Shera papers; CWRUA: Phyllis Richmond papers], and the American Society for Information Science and Technology Records, 1925-2001 at the Special Collections Library at the University of Michigan [UM: Special Collections Library]. It will also extend earlier research on SIG Classification Research (La Barre, 2003; La Barre, 2004).

Established in 1937, ADI had three major initiatives that drove this organization, (1) One big library (2) an auxiliary publication serve, (3) one big journal and the concept of the (4) world brain. By 1958, enthusiasm began to flag and the society entered a new phase of efforts which focused on building strength and endurance which lasted until 1966. During this period, anchored by funding from the National Science Foundation, ADI initiatives included: formation of a secretariat, creation of regional and student chapters, a new logo and code of ethics for the society, demarcation of the territory of documentation and establishing diplomatic relations 
with cognate societies, increased international efforts and lastly in 1966, formation of special interest groups or SIGs.

Special interest groups were a cherished vision of Hans Peter Luhn, who saw these as a way to "provide forums for the informal and formal exchange of ideas among individuals who shared common concerns in the emerging field of information science" (UM: Box 58). Luhn and others looked carefully at the growth of Special Interest Groups and Special Interest Committees in cognate societies such as American Computing Machinery (ACM) and the Institute of Electrical and Electronics Engineers (IEEE). ACM SIGs such as SIG/ART (artificial intelligence) in 1960, SIG/MIS (management information systems) in 1961, and SIG/UCC (university computing centers) in 1963 were the models upon which the first ADI SIGs were formed (Revens, 490-491).

A preliminary visit to the ASIS\&T records at the University of Michigan indicates that SIG cabinet meetings began in 1966. Membership figures from this year indicate the existence of seven formally affiliated SIGs: Education for Information Science, Library Automation and Networks, Information Analysis Centers, Classification Research, Biomedical and Chemical Information Systems, Reprographic Technology and Computational Linguistics. Membership in these SIGs grew rapidly, from a total of 213 in February of 1966 to 2495 by 1968. [UM: Box 60].

This inquiry begins with the story of SIG/Classification Research, of one of the original seven. In 1959, the April issue of ADI News Notes announced the election of C. Dake Gull as President of the American Documentation Institute, and the first meeting of the Classification Research Study Group at the upcoming May meeting of the Special Libraries Association in Atlantic City, and a second meeting at the American Library Association meeting in June (Atherton, undated; Atherton, 1959, p. 329; Richmond, 1960, p. 196; Richmond, 1969, p. 145-146). As part of this informal affiliation with ADI, the founders of the CRSG, including Phyllis Richmond, Pauline Atherton and Jesse Shera, agreed to form the ADI Classification Research Committee (CRC). The third meeting of the CRSG occurred in October at the October ADI meeting, at Lehigh University in Bethlehem, Pennsylvania. The CRSG decided not to formally affiliate with any group, but to maintain their "no strings attached" affiliation with ADI (News Notes, p. 196, Richmond, 1958, p. 236).

By 1959, ADI began to pressure the to pledge fielty. James Bryan, the Executive Chair of ADI wrote to Richmond "our suggestion is that you start a group primarily devoted to classification research, primarily affiliated with ADI with membership (or affiliate membership) in ADI required." (UM: Box 58]. Laurence Heilprin, who assumed the Presidency after Luhn's death also contacted Richmond with further incentives, "If formed, this will be the first ADI SIG - other potential SIGs are in library automation, information networks, reprography, technical writing, and copyright." 
By December 1965, Dake Gull - then president of ADI challenged the independence of the CRSG and directed the ADI Council to notify the CRSG of the incompatibility of continuing their informal affiliation. Gull threatened to replace the CRSG with a Committee on the Organization of Information (COI). The Council urged the CRSG to formally seek ADI section status. Instead, the members of the CRSG reaffirmed their independence, jointly submitted their resignations and recommended reinstituting the Committee on Organization of Information [Atherton, undated CWRUA 27DD9 1:1]. Records from the Committee on Organization of Information appear in the ASIS\&T archive from 1961-1965. Yet by 1966, this tempest in a teapot had seemingly blown over when SIG Classification Research was formed with Richmond as chair.

By consulting documentation held at the University of Michigan on the development of other SIGS, other periods of tension or reevaluation between ASIS and its SIGs are clearly evident. Keenly aware of activities in other cognate groups like the CRSG, ADI fellows worked hard to convince other groups to take part in the development of Special Interest Groups. Not everyone was keen to join. At the same time that the tempest was brewing with the CRSG, G.S. Simpson (Battelle) after being nominated as chair pro temps for SIG/ Information Analysis Centers reported back to headquarters, "I met with a number of directors and professional analysts, many of whom are scientists and engineers with only a marginal interest in documentation." He was not confident that this group would ever get off the ground in early 1966. (UM box 60).

In 1966, Eric Boehm (then president of the American Historical Association) declined Howard Dillon's invitation to start a SIG focused on history by issuing a counter-invitation to instead establish a group for historians of information science. In internal correspondence at headquarters, Howard Dillon responded to this invitation, "I believe we should point out...that historians actively interested in information science will not be served well by withholding themselves from our society." (UM: Box 58).

By 1967, most of the misunderstandings and hard feelings had been smoothed over with the result that the following seven SIGs had been formed and agreed to provide programming at the annual meeting. Classification Research (CR), Automated Language Processing (ALP), Reprographic Technology (RT), Library Automation Networks (RT), Information Analysis Centers (IAC), Biological and Chemical Information Systems (BC), Behavioral and Social Sciences (BSS). SIG CR's program was: How can Mr. MITS Best Construct a Classification Scheme? The abstract indicated that the intended emphasis was on operational and fundamental aspects of classification with a maximum of help for the user and a minimum of definitions and dogma. Four panelists presented different approaches to the problem: representing traditional librarians: Pauline Atherton, representing statistical/automatic approaches: Harold Borko, representing the logical / mathematics approach : Donald J. Hillman and representing the psychological/philosophical approach: William J. Paisley. 
(UM: Box 59).

Periods of difficulties were not limited to the formation phase of SIGs. Another of these instances occurs with archival material that documents the formation of an ad hoc task force on SIGs (1975-1976). In 1980 Bob Tannehill wrote a position paper The essence of SIGs, which calls into question issues of SIG purpose, governance and finances [Tannehill, October 1980] and resulted in a series of changes and responses by ASIS. Issues around the formation, reformation and death of SIGs across the years have contemporary resonance for the future of SIGs and ASIS\&T. This is just a very early briefing on the progress of this research. Once completed, this research will capture the broad arc of the inception, transmutation, and waning of SIGs as part of the ASIS\&T experience from 1959-1980 and possibly serve as an inspiration for members as ASIS\&T moves forward to the next seventy-five years.

\section{References/ Sources Consulted}

ASIS\&T (American Society for Information Science and Technology_. (2012). Special Interest Groups (SIGs). Retrieved 3/19/12 http://www.asis.org/SIG/sigs.html

Atherton, P.; Kent, A.; Oellrich, G.; Shera, J.; Richmond, P. (undated) 1959/1960 Classification Research Committee Report (undated) [CWRUA 27DD9 1:1].

Atherton, P. (1959). Two meetings sponsored by the Classification Research Study Group. News Notes , American Documentation, 10(4): p.329

Bates, M. correspondence and personal papers.

Classification Research Study Group. (1959). American Documentation Institute

Classification Research Committee, Annual Report 1959. Unpublished document held in the Case Western Reserve University Archives. 27DD9 1:1.

La Barre, K. (2003). Look back to look forward: The Classification Research Study Group and SIG/CR. In Jens Eric Mai, Claire Beghtol (Eds). Advances in Classification Research. No. 13, pp. 6-13.

La Barre, K. (2004). Weaving webs of significance: The Classification Research Study Group in the United States and Canada. In W. Boyd Rayward \& Mary Ellen Bowden (Eds). Proceedings of the 2002 Conference on the History and Heritage of Scientific Information Systems, pp. 246-257. Medford, NJ: Information Today.

News Notes, (April 1959) ADI announces slate of officers. American Documentation 10 (2): p. 159.

Revens, L. (1972). The first twenty five years: ACM 1947-1962. Communications of the ACM15 (7): 485-490. 
Richmond, P. Classification Research Study Group meets with ADI News Notes , American Documentation, 11:2 (1960:Apr.) p. 196.

Richmond, P. (1958). Classification research study groups. Library Resources \& Technical Services, 3(3): 236.

Richmond, P. (1969). Classification Research Study Group. In: A. Kent and J. O. Williams (Eds.), Encyclopedia of library and information science (Vol. 5, pp. 145-146). New York: Marcel Dekker.

Tannehill, R. (October 1980) The essence of SIGs. UM: Folder: Essence of SIGs. Box 90. 